Teologia i Moralność, volumen 14(2019), numer 2(26)

doi: 10.14746/TIM.2019.26.2.12

ORCID: 0000000156343078

PRZEMYSŁAW SAWA

University of Silesia

Theological faculty

\title{
Catholic doctrine and spirituality and the contemporary understanding of sexuality
}

An evident clash between different views on sexuality has been observed over the last several decades. The social revolution of the 1960s is a symbolic beginning of a new understanding of sexuality, a morality of sexual activity and the concept of sexuality itself, including various forms of sexual expression. Perhaps nowadays this new understanding is one of the greatest lines of division in the legal, social and religious spheres within societies. Some people consider this new vision of human sexuality as liberation, while others view it as devastating attack on values and consequently on every human being. The former group perceive that liberation as the fulfilment of the human person, while the latter see in this a tendency towards the annihilation of society. There seem to be many generalisations, oversimplifications and much shallow analysis in this discussion. We may look for the reason for that revolution: is it human passion and an attempt to create a new world or is it perhaps as a result of improper Christian reflection, in some dimensions, on sexuality, which focused on its moral aspects, while disregarding spiritual discernment. At the time of such polarisation of attitudes, a clear Christian voice is necessary. Therefore a courageous proclamation is needed of the Christian vision of what it means to be human. This vision must include human sexuality and must draw from the deepest biblical, doctrinal and spiritual resources.

The main issue might be summarised in the following question: what are the doctrinal, theological and spiritual principles of the Christian understanding of sexuality ${ }^{1}$ ? A proper setting of that issue not only broadens the horizons

\footnotetext{
1 The study concerns catholic point of view.
} 
of Christians but also equips them to engage intelligently with widely spread errors and views. After presenting the context of the discussion, the biblical and dogmatic principles of Catholic discourse about the body and sexuality, including historical considerations of particular moral evaluations will be presented. After this responses to the challenges of the modern world will be presented, challenges which the Church must meet. The most recent document on Catholic Education Man and Woman He Created Them is helpful in this regard.

At the beginning, it is important to stress the positive attitude of Christianity towards sexuality. As Anselm Grün remarks: "sexuality is a source of spirituality, and eros may lead man to the unity with God" (Grün, Reild 2006, p. 6; my translation). The Christian mystic tradition, which tends to present the unity of all aspects of human nature provides us with resources for such an approach.

\section{The debate over the basics}

At the beginning it is important to present the contexts of the main points of contention between the traditional Christian vision of sexuality and the contemporary tendencies, fashions and ever increasingly radical legislative enactments.

\subsection{Terminological problem: gender and sexuality}

Terminology is one of the difficulties in the present dispute. Nowadays, the terms "gender" and "sexuality" are used quite interchangeably. This impacts on the moral evaluation of particular way of behaving, since for many people their physical sex life is for them the full expression of their sexuality. Another issue arises when it comes to the redefinition of sex, where an apparent transition is taking place from grounding it in nature to grounding it in a social, individual and experience based definition. In contrast, a differentiation between gender and sexuality is necessary. Gender in particular expresses the identity of the human person as a man or as a woman and relates to physical features. Whereas sexuality is a term given a broader meaning, embracing all activity of a person, including sensitivity, a way of reacting to stimulation, a form of experiencing self in relation to others, activity of the emotional, individual and cognitive spheres. Finally, it is all about the ability to love, the ability to accept other persons and respect the other. In this way the social aspect of life is also 
brought to fulfilment ${ }^{2}$. At the same time this safeguards against the depersonalisation of others.

Given this differentation, it is vital that the understanding of the essence of sexual intercourse be not reduced merely to its physical and sensual aspects alone. This is particularly important in the context of our understanding of the gift of celibacy, where being unmarried and remaining chaste are not considered to be a negation of sexuality but are a particular way of accepting it. Thus, the denial of sexuality by celibates would be inappropriate since it would be a deformation of one's own identity and one's way of experiencing oneself. The Church maintains that the celibate way of life is a prophetic sign of God's love and His primacy in the life of the individual and of society ${ }^{3}$. If, after all, sexuality is about love, which is a gift of self, then celibates live out that gift for others as well, although they do not exercise it in an erotic way, nor in a way that is exclusive to one person. Rather they direct their love to a wider group of people. Thus they can be an appropriate point of reference for the lives of men and women.

\subsection{Anthropological problem: man's autonomy or restricted freedom}

The other axis of the ideological dispute is freedom, which is desired by every human and in that freedom a person is being fulfilled. This natural right and the inherent need of man are God's gift to humans at his creation. Nevertheless that freedom may be restricted when lived out in an improper way. Sin, which steals, kills and destroys (see Jn 10,10b; Rom 6,23) is the cause of this. This passage can refer to human sexuality. Lawlessness and the autonomy of the human person autonomy, both of which are widely promoted in the modern world, result in a serious crisis for the individual and for the whole community. An increasing sense of loneliness, instability of interpersonal relationships, weaker ability to sacrifice for the other, disorders of one's own identity, a sense of exploitation and the spread of sexually transmitted diseases serve to illustrate some of the consequences. All this is a consequence of disobedience to God.

\footnotetext{
2 "Me and you unite in $u s$. It does not mean that two people cannot see anything apart from each other, but it should be understood as a reality that refers to the whole society. [...] Two people locked in within their relationship are doomed to failure. On the contrary - a couple ought to be open, giving themselves to others" (Cascone 2002, p. 19), my translation.

3 "[...] virginity indicates human's origin in the God's act of creation, it also suggest his final destination, that is God himself. Virginity reveals deep mystic relation that connects every human being with the One, who created him, allowing him to search and find full satisfaction of the desire for love only in God" (Cencini 2005, p. 37), my translation.
} 
One must remember that sexuality itself is not sinful. It can be exercised, however, in either a wholesome or a sinful way. Yielding to sin limits sexuality as a language of love. Finally it leads to uncertainty and insecurity. This is demonstrated in the biblical passage about the fall, when after sin, Adam and Eve experience shame before each other, and a rupture in their trust in God was the reason for this. It cannot be interpreted only emotionally or sensually but also as something deeply spiritual. Decisions which are contrary to God's law lead the human being to experience the encroachment of death in particular areas of his life which ultimately leads to eternal death. This is why it is sin which is the dimension that limits us as humans. The discussion around this does not limit one's freedom, but to the contrary, it secures that liberty ${ }^{4}$.

\subsection{Moral problem: liberalism and rigorism}

Tension in any discussion on bodiliness and sexuality happens with the contraposition of laxism and rigorism. It seems that modern ethics is more and more liberal in its attitude: setting personal decision making as an explanation for particular actions. Laxity is very common too, whereby simply a doubt about a moral standard is reason enough for someone to consider it as irrelevant and may even justify its transgression. On the other hand there is also the danger of rigorism, which excessively seeks to find sin in many different behaviours without adequate consideration of all the particular circumstances: the recognition of God's authority, the experience of a relationship with God, the familial upbringing, the impact of the environment and culture and the personal limitations. This discernment is necessary, a discernment which takes into account, not only the matter of transgression but, additionally, the intention of the individual and the circumstances that individual finds himself in. A person's behaviour cannot be separated from his whole life. Proper discernment has nothing in common with relativism but represents the interpretation of truth with regard to a particular person.

\subsection{Perception problem: erroneous approaches}

Two opposite attitudes towards sexuality may be observed nowadays. Hedonistic tendencies limit sexual activity to an issue of technique while the other extreme considers sexuality as a dangerous area. The former attitude leads

4 The statistics show increasing number of people addicted to sexual sensation (e.g. pornography). That reflects progressive restriction of human freedom. 
to excessive exaltation of the body, leading eventually to diminishment of the person, while the latter attitude leads to the disrespecting of corporeality, as we saw in the past in the ideas of the heretical Cathars and Jansenists, who undoubtedly subscribed to the primacy of that which is spiritual, leading them to attempt to overcome their sexual needs and live in total chastity. That way the idea of virginity persevered, although it was understood not as one of many paths available for faithful but as a higher level (although still undoubtedly), enabling deep spiritual life. In fact it was a misinterpretation of the biblical message.

One must acknowledge the fact that hedonism and "body-centrism" impoverishes humanity, obfuscating its spiritual and supernatural dimension. The notion of reducing the body, with its value, is a manifestation of illusory angelism and a deformation of human nature. The above mentioned attitudes are destructive of the way we live out our humanity ${ }^{5}$. , However, the unity of all these aspects of human nature is our destiny. "Man is truly himself when his body and soul are intimately united; the challenge of eros can be said to be truly overcome when this unification is achieved. [...] Only when both dimensions are truly united, does man attain his full stature" .

\section{Biblical and ecclesiastical basis of understanding bodiliness and sexuality}

Bodiliness and sexuality has been a subject of the biblical message and the Church's teaching over the centuries. One must observe the development of the doctrine and the gradual corrections and clarifications, which contrast with modern moral evaluations of particular ways of behaving.

\subsection{Biblical evidence ${ }^{7}$}

The biblical teaching about sexuality is based on the following passage: "So God created man in his own image, in the image of God created he him; male and female created he them. And God blessed them, and God said unto them, Be fruitful, and multiply" (Gen 1,27-28) This passage shows the fact of creation and the task given to man: "and replenish the earth, and subdue it" (Gen 1,28b). However in the other passage about the creation of man the fol-

\footnotetext{
5 " $[. .$.$] sex drive is between two radical, opposite and in many ways destructive tendencies:$ from one side there is suppression and reducing and on the other side instrumental and voracious exploitation" (Fijałkowski 1991, p. 13), my translation.

6 DCE 5.

7 For wider study cf. Babik 2003.
} 
lowing is emphasised: "And the rib, which the Lord God had taken from man, made he a woman, and brought her unto the man. And Adam said, This is now bone of my bones, and flesh of my flesh: she shall be called Woman, because she was taken out of Man. Therefore shall a man leave his father and his mother, and shall cleave unto his wife: and they shall be one flesh" (Gen 2,22-24). Considering the above passages, equality of vocation rather than the differences of the sexes should be noted. This creation in the image and the likeness of God embraces both man and woman in their diversity. In the Hebrew original this is especially emphasised. In the first part, God created man, a word ha adam (humankind) is used, which is a collective noun referring to the human race. However, in the second part we find the nouns zakar (male) and quebah (female), which can be used in reference to animals too. On the other hand in the Yahwist narrative the words ish (man) and ishshah (woman) appear, used only in reference to human persons, and which reflects the truth that the refference point for the human should be God and not that which he has in common with the animals. At the same time, he discovers his call to relationality, fellowship and unity with other human persons. It has to be stressed that this unity is not only referred to as something spiritual but as something physical as well. It is carnal. Thus sexuality should be perceived as the area of deep encounter between man and woman.

The Word of God then does not separate love from sexuality. The entire created order was made out of God's love towards creation ${ }^{8}$. Thus a man attains his fulness through love for the Creator, for others, and for self ${ }^{9}$. This is justified by the fact that the Bible presents the relationship between God and man using the language of sexuality and intimacy ${ }^{10}$. Man's longing for God is presented similarly, according to the allegoric biblical interpretation in Jewish and Christian tradition: "All night long on my bed I looked for the one my heart loves; I looked for him but did not find him. Scarcely had I passed them when I found the one my heart loves. I held him and would not let him go till I had brought him to my mother's house, to the room of the one who con-

8 "For this is how God loved the world: he gave his only Son, so that everyone who believes in him may not perish but may have eternal life" (Jn 3,16).

9 "You must love the Lord your God with all your heart, with all your soul, with all your strength, and with all your mind, and your neighbour as yourself" (Lc 10,27).

${ }^{10}$ For example: "I shall betroth you to myself for ever, I shall betroth you in uprightness and justice, and faithful love and tenderness. Yes, I shall betroth you to myself in loyalty and in the knowledge of Yahweh" (Hos 2,21-22). In this contexts comparing Israel's sinfulness to adultery is not surprising, e.g. "Though you, Israel, play the whore, there is no need for Judah to sin too. Do not go to Gilgal, do not go up to Beth-Aven, do not swear oaths «by Yahweh's life», for Israel is as stubborn as a stubborn heifer; so is Yahweh likely to pasture him like a lamb in a broad meadow? Ephraim has made a pact with idols - let him alone! Their drunken orgy over, they do nothing but play the whore, preferring Shame to their Pride" (Hos 4,15-18). 
ceived me. into my mother's house, and into the chamber of her that conceived me" (Song of songs 3,1.4) Nevertheless, the first level of meaning is the appreciation of the beauty of man and woman's mutual longing for each other. Thus the cherishing of sexuality and the very erotic response of the beloved is not so surprising:

How beautiful you are, my darling! Oh, how beautiful! Your eyes behind your veil are doves. Your hair is like a flock of goats descending from the hills of Gilead. Your teeth are like a flock of sheep just shorn, coming up from the washing. Each has its twin; not one of them is alone. Your lips are like a scarlet ribbon; your mouth is lovely. Your temples behind your veil are like the halves of a pomegranate. Your neck is like the tower of David, built with courses of stone[a]; on it hang a thousand shields, all of them shields of warriors. Your breasts are like two fawns, like twin fawns of a gazelle that browse among the lilies. Until the day breaks and the shadows flee, I will go to the mountain of myrrh and to the hill of incense. You are altogether beautiful, my darling; here is no flaw in you (Song of songs 4,1-7).

An erroneous interpretation of the solely procreative aspect of sexuality is disavowed in the above passages. On the contrary, the relationship between the spouses comes first, which is their love and unity and only then is life transmitted ${ }^{11}$. Little wonder then, that the Bible encourages spouses to sexual intercourse: "Enjoy life with your wife, whom you love, all the days of this meaningless life that God has given you under the sun - all your meaningless days" (Ecles 9,9) and "May your fountain be blessed, and may you rejoice in the wife of your youth. A loving doe, a graceful deer - may her breasts satisfy you always, may you ever be intoxicated with her love. Why, my son, be intoxicated with another man's wife? Why embrace the bosom of a wayward woman?" (Proverbs 5,18-20).

The New Testament carries on this understanding of sexuality. The unity of marriage is the starting point. During the controversies around divorce, Jesus affirms, referring to Genesis: "For this reason a man will leave his father and mother and be united to his wife, and the two will become one flesh' So they are no longer two, but one flesh" (Mt 19,5-6a). This conjugal unity ought to be cherished, since our wounded human nature lives us prone to sexual sin. That is why St Paul suggest that any sexual abstinence within marriage should

${ }^{11}$ Procreation is partaking in the God's act of creation. Pope Francis reminds: "the fruitfulness of the human couple is a living and effective "image", a visible sign of his creative act" and "a symbol of God's inner life" (AL 10-11). 
only be temporary ${ }^{12}$. This approach does not exclude virginity or widowhood as long as these are lived out in chastity (see 1 Cor 7,1-16.25-38).

The Bible presents any distortion of the harmony of life intended by God as also affecting the human being in his sexuality. After all, the consequence of the Fall was a sense of shame and nakedness, which they tried to overcome by making patches and coverings of animal skins given them by God. That expresses the truth of wounded sexuality and its possible misuse. What follows in the Holy Scriptures presents accounts of the breaching of God's law in the sexual sphere, for example David's sin. Then it is understandable that St Paul demands that Christians do not perceive liberty as an occasion for indulging the flesh $(\mathrm{Ga} \mathrm{5,13).} \mathrm{One} \mathrm{must} \mathrm{be} \mathrm{aware} \mathrm{of} \mathrm{tension} \mathrm{between} \mathrm{flesh} \mathrm{and} \mathrm{spirit} \mathrm{and}$ surrender his life to the guidance of Holy Spirit (Ga 5,16-25). This demands a transformation of life, through abandonment of a sinful lifestyle ${ }^{13}$ and fixing one's eyes on the goal, which is participation in eternal glory. This allows communion with Jesus Christ, possible when one "considers the things that are above" (see Col 3,1-4). It was clearly illustrated by Jesus in His reply to the story of the woman, who had seven husbands in her life, told by Sadducee: "At the resurrection people will neither marry nor be given in marriage; they will be like the angels in heaven." (Mt 22,30).

\subsection{Sexuality in the history of Christianity}

There were different stages of the understanding of sexuality in the history of Christianity. Those main tendencies should be presented with their social background. Christians lived in a pagan culture full of permissiveness, including the institution of ritual prostitution in some of the pagan temples. The Church then stood against unchastity, adultery and a sacral understanding of sex (as a way to salvation). Therefore, Clement of Alexandria (Titus Flavius Clemens) in his letter to Diognetus assures of Christian's complying with the state of chastity: "Like others, they marry and have children, but they

\footnotetext{
12 "You must not deprive each other, except by mutual consent for a limited time, to leave yourselves free for prayer, and to come together again afterwards; otherwise Satan may take advantage of any lack of selfcontrol to put you to the test" $(1$ Cor 7,5).

13 "You were to put aside your old self, which belongs to your old way of life and is corrupted by following illusory desires. Your mind was to be renewed in spirit so that you could put on the New Man that has been created on God's principles, in the uprightness and holiness of the truth" (Eph 4,22-24). "For you can be quite certain that nobody who indulges in sexual immorality or impurity or greed - which is worshipping a false god - can inherit the kingdom of God. Do not let anyone deceive you with empty arguments: it is such behaviour that draws down God's retribution on those who rebel against him. Make sure that you do not throw in your lot with them. You were darkness once, but now you are light in the Lord; behave as children of light!" (Eph 5,5-8).
} 
do not expose them. They share their meals, but not their wives. They live in the flesh, but they are not governed by the desires of the flesh. They pass their days upon earth, but they are citizens of heaven." (Letter to Diognetus V,6-9). Clement of Alexandria emphasised the importance of marriage, to counteract erroneous views spread among the baptised. Addressing these people he said: "There are people who call marriage fornication and claim that it was given by the devil. And in their pride they say, that only they follow the Lord, who has neither married nor possessed anything material in this world." (Danielou 1984, p. 108; my translation). In turn, Jerome paid attention to the nature of married life: "The wise man ought to love his wife wisely, not passionately. $\mathrm{He}$ should control his passions and not hastily seek for the physical intercourse. There is nothing more priceless than loving one's own wife as a mistress [...]" (Flandrin 1998, p. 194; my translation). These words emphasise emphasize the spiritual and personal character of sexual activity, incorporating rationality and respect for the other person.

The next phase of the discourse on sexuality took place in the Middle Ages. Thomas Aquinas emphasised the great driving force of love, which enables one to sacrifice. At the same time he showed that martial unity is of both a spiritual and physical aspect, in a union of bodies and hearts (Thomas Aquinas, I-II, q. 27-18;III, q. 44 a. 1). Again philosophical and theological thoughts referred to Aristoteles' writings. He highlighted the pleasure associated with the act. Only the means to that pleasure is subject to moral evaluation. St Thomas' teaching follows this logic. He claimed that sexual pleasure within marriage is good, although it shouldn't be longed for (Thomas Aquinas I-II, q. 34 a. 1). Peter Abelard deprived marital life of its sanctifying value. ${ }^{14}$ As a consequence of this, in 1679 Pope Innocent XI considered sexual intercourse exercised solely for the purpose of pleasure to be a venial sin (Knotz 2001, p. 50; my translation).

It should be mentioned that alternative views were also expressed. Denis the Carthusian (1402-1471) highlighted the role of spiritual and physical love, the goodness of conjugal act and fact that conjugal act should serve for their salvation. On the other hand, Martin Le Maistre (1432-1481) considered sexual intercourse without procreative intentions as immoral. There were theologians who emphasised the importance of a community of love (Hugh of Saint Victor, Tomás Sánchez and Basil Ponce de Leon). This was especially emphasised in German moral theology at the turn of XVIII and XIX century. Herbert Doms began to preach bravely that the conjugal act is a sign of love and com-

14 „Marriage was instituted prior to the first fall, not as a remedy but as a sacrament and duty. After the first fall it became a remedy for deprivation of the lust of the flesh" (Lombard, IV,2,3), my translation. 
mitment between spouses and that it incorporates the whole being of person, including his psyche and spirit (Knotz 2001, s. 51-53). Gradually that thinking found its place in the Church. The declaration by Pope Pius XII that sexual life brings spouses joy and pleasure, which is why they cannot be deprived of it, even though moderation is necessary, was an echo to that transformation ${ }^{15}$.

The modern teaching of the Magisterium emphasises the importance of an integral vision of human life. John Paul II, following Paul VI's teaching, highlighted the harmony between conjugal love and the responsible transmission of life (FC 32). Although the fact that sexual activity is a way of expressing love, in which the person offers himself to the other cannot be omitted. Coordinating of the spiritual and carnal sphere is necessary in subjective approach to the other person. That cannot be achieved without growing in the virtue of chastity and educating people in self-control. The call to holiness is the appropriate perspective for human life, including sexuality (see FC 32-34).

\section{The Doctrine: Christian understanding of bodiliness}

Without presenting a proper Christian understanding of bodiliness and humanity in general a moral discourse with the modern world would be incomplete. Many Christians often lack in a proper contextualisation and deeper understanding of the justification of particular moral teachings regarding sexuality. Thus, identification of the principles of theological anthropology, especially the incarnational model with its application, is necessary.

\subsection{Christian anthropology: testimony of harmony}

The Christian anthropology begins from the fact the human beings are created as a man and a woman, in the image and likeness of God, which implies relationality and a calling to glory. Therefore, human life cannot be understood only in a horizontal dimension (in relation to others), or only in relation to self (self-understanding, self-decision). It must include the vertical dimension, which is relation between the human and God, who desires personal relationship with everyone. That dimension is fulfilled in living out the vocation to

\footnotetext{
15 „Quello stesso Creatore, che nella sua bontà e sapienza ha voluto per la conservazione e la propagazione del genere umano servirsi dell'opera dell'uomo e della donna, unendoli nel matrimonio, ha disposto anche che in quella funzione i coniugi provino un piacere e una felicità nel corpo e nello spirito. I coniugi dunque nel cercare e nel godere questo piacere, non fanno nulla di male. Essi accettano quel che il Creatore ha loro destinato. Nondimeno anche qui i coniugi debbono sapersi mantenere nei limiti di una giusta moderazione" (AAS 1951, p. 851).
} 
the womanhood and manhood. In view of these facts, any protest against the differentiation of the sexes is an objection against God's act of creation, and an attack on our understanding of what it means to be human. Thus the Church proclaims the meaning of the natural differentiation between the sexes with great determination. The Congregation for the Doctrine of the Faith reminded us that "it is from sex that the human person receives the characteristics which, on the biological, psychological and spiritual levels, make that person a man or a woman, and thereby largely condition his or her progress towards maturity [...]" (PH 1).

The Christian vision of the human being highlights another important truth: the temporal and eternal dimensions and the physical and spiritual meet in each person. Although the Church undoubtedly proclaims the primacy of the spiritual and sees eternity as the reference point and the greatest perspective for life, she does not rebuke temporality and corporeality (materiality). Quite to the contrary, those dimensions find secure foundation in church teaching. In view of the situation, the maturity should be perceived in the harmony of those elements and their mutual relation.

The third aspect of Christian anthropology is the relationality inscribed in a human nature. A healthy life is impossible without the reference to other people and God. That is how likeness to God is revealed. The meeting point is partaking in the glory of the Father and the Son in eternity, that will be shared in the community ${ }^{16}$. Living out that reality in temporality goes beyond existing alongside another, it assumes an aspiration to the genuine communion and exchange of love. Thus the family is a special area of discovering and exercising interpersonal relationships. The family, as the foundation of society, is a gift from God and is authorised by God's law ${ }^{17}$. In that context, any attack on the family is a form of assault on creation, which results in social upheaval. Considering the above, the Church, with great determination, calls for respect for the family constituted through marriage. Family creates the environment for the bringing up of children. At the same time, it is understandable that children enjoy a right to "grow up in a family with a father and a mother capable of creating a suitable environment for the child's development and emotional maturity" and "continuing to grow up and mature in a correct relationship represented by the masculinity and femininity of a father and a mother and thus preparing for affective maturity" (Francis 2014, p. 26-27). Therefore children can learn how to recognise the value and the beauty of the differences between the

16 " $[\ldots]$ God wanted all fullness to be found in him and through him to reconcile all things to him, everything in heaven and everything on earth, by making peace through his death on the cross" (Col 1,19-20).

17 That natural right to marriage as relationship between one man and one woman results from the fact of creation and natural complementarity of sexes, revealing the beauty of God as the Creator. 
two sexes, along with their equal dignity, and their reciprocity at biological, functional, psychological and social levels. Thus sexuality can be recognised as an enrichment of the whole person - body, emotions and soul - and ability to sacrifice (FM 38). That mission should be supported by the school, especially Catholic schools. Hence, the postulate of proper language to be used in the social-educational process, leading to gradual maturation, respecting morality and spirituality. An appropriate formation of the teachers and pedagogues is necessary to achieve that goal ${ }^{18}$.

\subsection{Incarnational model: protection of integrity}

The Christological (incarnational) model is essential in the Christian understanding of the human being. It reffers to a life style, thinking, activity and spirituality. The harmony of all aspects of life and respect to various orders is the deepest expression of that model. The Council of Chalcedon's definition of the two natures of Christ can be applied, through analogy, to human life: in two natures, unconfused, unchangeably, indivisibly, inseparably. This understanding is a consequence of Incarnation of the Word and provides an example to living out its life as a human being, involving a positive attitude to body without elimination of the spiritual ${ }^{19}$. This protects Christian thought from fideism and over-spiritualism on one side, and hedonism and body-centrism on the other. Thus, several essential dogmatic principles of spirituality and moral discernment may be determined. First of all "divine" and "human" are not opposed in human life and God's omnipotence does not endanger human freedom. A key to understanding this is the relational nature of mean cooperation between God and humanity. This means one's relativity is not in opposition to God's excellence and both realities can meet together, without diminishing the other ${ }^{20}$. Consequently separation between sacrum (that which

18 "Such a formation goes beyond the purely necessary professional training and addresses the more intimate aspects of the personality, including the religious and the spiritual" (WW 80).

19 " [...] Christianity is a form of spiritual life where our deepest and most inner relation to God- God who is truly personal in His transcendence, is fully recognised and formally preserved [...]. Christian spirituality is not only based on the unassailable, unshakable idea that God is a person. Spiritual life is the effect of His revealing to us as a person. If that truth of God revealed to man in Christ as Somebody is lost, there cannot be any Christian spirituality worth of its name [...] the entire spiritual life of the Christians is developed and shaped on the fact that, that God- as I believespoke to a man and His Living Word was made flesh and lived among us. In other words, Christian spirituality is not based on some concept of God, nor on an idea that He is a person but on the very Christian believe that accepts the Word of God, the Word that let us know Him, that gave Himself to us in Jesus Christ" (Boyer 1982, p. 12-14), my translation.

20 "God's transcendence is not as it seems to us; that transcendence is not afraid of our immanence [...] God does not die in contact with what is relative.” (Gesché 2005, p. 265). „If our God 
is sacred) and profanum (that which is profane) is withdrawn (Waldenfels 1997, p. 44) and a "materialisation" of what is spiritual takes place. In these circumstances, separating these areas of human life would be inappropriate. Thus Jerzy Szymik is right saying: Christianity is a true spiritualisation of life only when it constantly becomes the embodiment of spirit" (see Szymik 2014, p. 301; my translation). Divine and human elements coexist, eternity and time, infinity and finitude interpenetrate (perichoresis).

Secondly, Christianity clearly proclaims the intimacy between God and humanity. The greatness of God cannot be exaggerated, because the mystery of Emmanuel, God-with-us, should be taken into consideration, although the distance between God and humanity should be manifested. The duality of "divine" and "human" should not be abolished either (Chantraine 2000, p. 173; my translation). It is necessary, however, to maintain appropriate proportions, so as to avoid reducing God to what is human and so as not to present the greatness of God as a kind of violence towards humanity (Gesché 2005, p. 266; my translation).

Thirdly, the incarnational model reveals the beauty of the human body. It cannot be reduced to an object or, on the contrary, to the absolute core of existence. Through the Incarnation of the Word flesh is significantly affirmed by God, although that process already began in the Old Covenant. The consequences of this are inalienable. If the human flesh reflects God's image, then it applies to gender as well, although God cannot be perceived within these categories. That image is best presented in humanity being communion-oriented: the unity is the only proper perspective for of love. Consequently, marriage is a picture of the love which is in God (Chrostowski 2000, p. 16-17; my translation). Regarding this, Christianity defends a positive vision of the flesh and protects anthropology from various extremes (Grossi, Ladaria, Lécrivain, Sesboüé 2001, p. 85-90; my translation). The foundations for such an approach lie in the acceptance of the fact of our creation by God, the Incarnation of the Word, the work of salvation through Christ, and the sanctification by the Holy Spirit. A moderate approach towards penitential practices and the disapproval of any degradation of the flesh are rooted in these convictions ${ }^{21}$.

Fourthly, Christian anthropology shows spiritual and bodily harmony in the human being, including mutual references between the soul and body. The body is a "substance of matter, its concretization, subsistence, fuller realisation. It is in every form an end, an aim and a proximal sense for amatter. It is a microcosm" (Bartnik 2000, p. 378; my translation). One cannot forget

is of kenosis, God that gives Himself in an episode of the history, then all that is relative should not fear death in contact with the Absolute". (Gesché 2005, p. 53), my translation.

${ }^{21}$ Of course there were many malpractice in this area over the centuries. 
that this bodileness refers to a person. Similarly the soul should be perceived as the principle of our self-consciousness, of thought, of personal subjectivity. Transcending of the body is achieved through the soul (Bartnik 2000, p. 387-389 $)^{22}$. So the conclusion is that a person is a reality that unites an aspect of body with an aspect of soul (in imitation of the hypostatic union in Jesus Christ). Taking all of the above into consideration, modern theological thought aims to see man as "a mysterious union of the opposites: soul and body create oneness, rooted in the act of creation and the work of redemption and salvation; wherein interior and transcendence shall have primacy; like salvation first regards soul, then body. A body and a soul separately do not form complete person; however soul is a principle of personal identity" (Sawa 2009, p. 333; my translation). Therefore there can be no jumbling of these aspects of a person not their separation.

In summary, Christian anthropology emphasises man's worth (with his freedom) and professing the greatness of God is not an annihilation of the human condition. Jerzy Szymik aptly expresses that idea: "The Christian paradigm of Incarnation presents in a great Christological vision of orthodoxy and orthopraxis, that the Person of Jesus Christ is proof that God does not decrease when man increases (and vice versa), and it is good for both God and man to be together in personal communion" (Szymik 2004, p. 95-96; my translation).

\subsection{Incarnational spirituality: harmonious lifestyle}

An incarnational spirituality, which results from this incarnational model, explores consequences of the Incarnation of the Word. It is expressed not only in harmonious acceptance of spiritual and physical orders, but in a positive reception of life, the bodiliness (including one's own sexuality), developing the ability to love, to be responsible, to be faithful, in imitation of Christ. A symmetry between God and man, eternal and temporal, supernatural and natural is necessary too. It affects the relationship with God, a relationship without fear, and without unnecessary distress regarding one's own bodiliness. At the same time protects humanity from the effects of a distorted autonomy autonomy. History, especially of the twentieth century, shows that "godless" humanism is hostile to humanity and deprives us of our liberty, because the relationship with Jesus Christ is crucial to maintaining one's liberty"23. So one does not

${ }^{22}$ For theological conceptions of "soul-body" relationship see Grossi, Ladaria, Lécrivain, Sesboüé 2001, p. 103-129.

23 " [...] the model of life of Sisyphus is abolished (symbol of a redundancy, an absurd of the efforts to improve one's life), similarly the model of Prometheus (a rebellion against God) and of Dionisos (a defication of the body) and of Apollo (racionality, harmony, consequency). All attempts 
need to resign from humanity in order to experience God (zob. Szymik 2004, p. 98$)^{24}$.

This truth has repercussions for Christian morality. Christ redeemed human nature burdened with sin and He is a model for our choices. Only love that presumes harmony of all areas of life should be a motive for one's choices.

\section{Spirituality and pastoral ministry: facing challenges of modern times}

The Christian vision of corporeality and sexuality outlined here is confronted with modern world views, which are often more and more aggressive towards the traditional anthropology. The Church is being challenged by a progressive ideology of the primacy of the body and the affirmation of sexuality, diverging of the teaching of the Magisterium with daily life of vast majority and advance of gender ideology.

\subsection{In view of primacy of the body and excessive affirmation of sexuality}

The sexual desires are being voiced even louder nowadays. Yet, the absolutisation of that sphere, putting it on an equal level with the need for food or sleep is a problem ${ }^{25}$. Yet sexuality is a way of expression of human being and his love. Excessive affirmation of corporeality limits people's experience to sexual excitement. It ends in the gradual closing off to spiritual experiences and the supernatural. It is expressed eloquently below: "Discovering gender as a field of exploitation for extracting the most intense sexual experience is

of creation of human separated from God, idolising the body always bring the civilisation of the death" (Sawa 2009, p. 335), my translation.

24 "[...] escape from self is not a progress towards Him" Similarly the opposite: ,denial of God does not broaden the space of human freedom. Deeper planting (In-carnation) in own's life isn't the right path to the true self neither to Him- always together, never apart"' (Szymik 2004, p. 104), my translation.

25 "Sex is not like any other aspect of physiology. In not a natural but cultural fate, that we express our experience related to food in a different way than those related to sex. We can publicly announce that we are hungry while sexual hunger is not voiced publicly. Eating in public is allowed while bean of public sex is a strong taboo in probably every culture; that prohibition is among constitutive constituent of humanizing [...]" (Kołakowski 1999, s. 55), my translation. "Satisfying a sexual drive is not necessary to survive unlike the need of food, water and sleep, which unsatisfied for a longer time may lead to termination of one's life. Even more, sex drive, at certain stage, provide gratification in fantasy and manipulation in own's body; [...] sex drive is more irrespective to external reality than ego" (Fromm 1992, p. 9), my translation. 
equal with killing ability to love" (Fijałkowski 1991, p. 27; my translation) ${ }^{26}$. It happens through the gradual reification of sexuality and various addictions on the grounds of sex, especially related to the internet (see Zwoliński 2014, p. 44-51.72-124; my translation). That leads to a depreciation of other spheres of human life, e.g. psyche and emotional spheres, religious and spiritual, moral and social dimensions. At the same time, addiction to the body and subordination to it increases, eventually turning against the body (see Dziewiecki 2000, p. 18-20; my translation).

A radical separation between physical and platonic love is an attempt to oppose the excessive affirmation of sexuality. This attitude is incompatible with the Christian view since the aspects of human reality mentioned above are not in contradiction. Biblical and Christian anthropology shows the unity of these aspects of human nature. Of course, the corruption of sin disrupts that initial harmony, but through the gift of salvation, even sexuality as an aspect of life experiences liberation, restoration and sanctification. It provides opportunity for love to become more creative. The spiritual life introduces grace into the experience of bodiliness and relationship. Thus it is possible to focus on the ultimate self-realization. Pope Benedict XVI said that "eros needs to be disciplined and purified if it is to provide not just fleeting pleasure, but a certain foretaste of the pinnacle of our existence, of that beatitude for which our whole being yearns" (DCE 4).

It should also be noted that Frequently cases of irregular situations make implementation of catholic understanding of sexuality (and marriage in general) more complicated. For example, of this might be: "trial marriages", de facto free unions, civil partnerships between baptised, singles after divorce or separation, baptised people who have remarried" (FC 79-84). Life in such circum-

26 Thus one must constantly discover martial love as a truly human love with all its aspects. "This love is above all fully human, a compound of sense and spirit. It is not, then, merely a question of natural instinct or emotional drive. It is also, and above all, an act of the free will, whose trust is such that it is meant not only to survive the joys and sorrows of daily life, but also to grow, so that husband and wife become in a way one heart and one soul, and together attain their human fulfillment.

It is a love which is total that very special form of personal friendship in which husband and wife generously share everything, allowing no unreasonable exceptions and not thinking solely of their own convenience. Whoever really loves his partner loves not only for what he receives, but loves that partner for the partner's own sake, content to be able to enrich the other with the gift of himself.

Married love is also faithful and exclusive of all other, and this until death. This is how husband and wife understood it on the day on which, fully aware of what they were doing, they freely vowed themselves to one another in marriage. [...] Finally, this love is fecund. It is not confined wholly to the loving interchange of husband and wife; it also contrives to go beyond this to bring new life into being [...]" (HV 9). 
stances demands from the Church a new way of presenting the Gospel truth and seeking new solutions for difficult situations (see AL 231-252.291-306).

\subsection{Inadequacy of life of faithful and the teaching of Magisterium}

The dissonance between Church teaching and the behaviour of the faithful becomes a pastoral and spiritual problem. On one side, the infiltration of world views foreign to the biblical and theological understanding of the body and sexuality into a Christian's awareness could be the cause. In these circumstances, a new apologetic and a new positive message of the Catholic vision of humanity including our sexuality is necessary. On the other hand, what seems it is also necessary that theologians and bishops would listen to what the faithful think and experience. Taking it all into consideration, one needs to take care to remain faithful to Revelation (though some clarification of the teaching may be possible) and discernment according to modern knowledge and people's mentality, including the particular circumstances of the each case.

\subsection{In view of the sexualisation of life}

Worth remembering is that gender and sexual sphere is developed not only physiologically but also socially through the culture (see WiśniewskaRoszkowska 1988, p. 12-30). Unfortunately, the crisis of modern societies and their gradual secularisation ${ }^{27}$ do not make experiencing an erotica and sexuality, reducing them to fulfilment of personal desires, especially the sex drive. Meanwhile human sexuality requires depth and harmony of all aspects of life. As Anselm Grün emphasises, this is one of the causes of the crisis among celibates, who abandon religious or monastic life. "Some clerics failed to change their own sexuality into the source of spiritual life, incorporate eros with mystic" (Grün, Riedl 2006, p. 7). "A copernican revolution" is needed in this matter. Włodzimierz Fijałkowski pointed out "it is not the spirit that spins around sexuality, forming a refined mist, but quite the opposite: the sphere of body and sexuality is transformed in order to express of what is personal and spiritual" (Fijałkowski 1991, p. 14).

27 A common sexualisation, propagation of sex, erroneous judgement of moral aspects of sexual behaviour, increasing number of people addicted to pornography and propagation of sexual deviation are being observed. See Misiaczek 1996, p. 71-80. 


\subsection{In the front of of gender controversy}

Modern times are marked with increasingly present gender ideology, presented in its various shades. Pope Francis, quoting final report of the Synod of Bishops on the family, provides definition of gender ideology. It

denies the difference and reciprocity in nature of a man and a woman and envisages a society without sexual differences, thereby eliminating the anthropological basis of the family. This ideology leads to educational programmes and legislative enactments that promote a personal identity and emotional intimacy radically separated from the biological difference between male and female. Consequently, human identity becomes the choice of the individual, one which can also change over time (AL 56).

Therefore, the Church's radical objection towards this idea of changing the understanding of gender and, in consequence sexuality, including various forms of expressing, is not surprising. One ought to be always aware of the illusory paths of a concept of what is human according to gender ideology. The Congregation for Catholic Education highlighted points that cannot be accepted regarding the biblical concept of human being. Above all it speaks of "a gradual process of denaturalisation, that is a move away from nature and towards an absolute option for the decision of the feelings of the human subject" (FM 19). As a consequence, the understanding of own's sexual identity and the concept of family become a changeable and unstable reality. That leads to an illusory understanding of liberty, that objectifies the human person and advances an existential void caused by a disorder of own's identity ${ }^{28}$. The Congregation drew attention to the risk of reducing the body to the status of inert matter, which when to then human will will become an absolute. That advances relativism and valuing one's social and cultural differences (gender) as more important than biological ones (sex) (FM 20). The two concepts: gender and sex, synonyms until recently, became separated in meaning, opposite of$\operatorname{ten}^{29}$. The attempt to legislate for that anthropology is a challenge for societies.

${ }^{28}$ A sociological research indicate a high percentage of suicide among people from LGBT community. It cannot be explained by homophoby in certain spheres because that tendency is noted in countries where single-sex marriages are allowed and the society do not depress homosexual or tranasgender people in any way. See Dlaczego homoseksualiści tak często popełniają samobójstwa? https://homoseksualizm.edu.pl/co-mowi-nauka/34-psychologia/183-dlaczego-homoseksualiscitak-czsto-popeniaj-samobojstwa [used: 2.07.2019).

29 "This separation is at the root of the distinctions proposed between various sexual orientations which are no longer defined by the sexual difference between male and female, and can then assume other forms, determined solely by the individual, who is seen as radically autonomous. Further, the concept of gender is seen as dependent upon the subjective mindset of each person, who can 
In fact, it leads to a serious distortion of social relationships and to canonical problems, e.g. the potential entering into the sacrament of marriage by a transgender person ${ }^{30}$.

There is another problem related to gender issue that has to considered. Absolutisation of an individual's feelings leads up to the setting up the morality on an individual basis,, momentary and changeable desire, without any axiology beyond the human person. Yet, the biblical command to accept God's authority in telling good from evil is still valid. The tree of knowledge of good and bad is a symbol of God's power to establish moral order. Our usurpation of that prerogative leads to death ${ }^{31}$.

In that difficult discussion, one must see some postulates that can serve as a meeting point. The following should be indicated: fighting unfair discrimination, educating the younger generation to respect others, growth in the area of discovering the value of womanhood (FM 15-18), emphasis on social roles and the healthy struggle against stereotypes. Yet, correct anthropology, based on sexual differences biologically grounded is the boundary point. Obviously, an issue of conducting people of distorted sexual identity still remains as a great moral and pastoral challenge.

\subsection{Christian guidelines towards understanding one's gender and sexuality}

The Church's understanding of gender and sexuality is based on the act of creation, which is decisive for our identity as humans. Pope Francis reminds us: "biological sex and the socio-cultural role of sex (gender) can be distinguished but not separated" (AL 56). Through the body and its reactions, the person communicates with others and expresses his identity. Biological science clearly emphasises the justice of sexual dimorphism; validation is found on genetic, endocrinological, neurological and physical levels. Thus the proposition of "neutral gender" or "third gender" is hard to accept. Womanhood and manhood are not just a social role assigned by tradition or a determinant of behaviour in particular settings. They express the essence of humanity, whose fulness is revealed in mutuality and complementarity. That is clearly evident in the man-woman relationship, especially in the marriage covenant and in

choose a gender not corresponding to his or her biological sex, and therefore with the way others see that person (transgenderism)" (FM 11).

30 The sacramental marriage then would be void.

31 "The woman answered the snake, We may eat the fruit of the trees in the garden. But of the fruit of the tree in the middle of the garden God said, ,You must not eat it, nor touch it, under pain of death. Then the snake said to the woman, No! You will not die! God knows in fact that the day you eat it your eyes will be opened and you will be like gods, knowing good from evil" (Gen 3,2-5). 
procreation. Therefore an identification of self ("I") takes place in confrontation with another ("you"). That serves as the appropriate basis for spiritual development. The human person discovers the deepest understanding of love as a gift of self, in giving and receiving, and that embodies relational nature of love.

Basic guidelines for creative experiencing of own's sexuality can be formulated in regards to Christian teaching and natural needs of people. Włodzimierz Fijałkowski at the beginning suggests openness to the adequate contact with persons of the other sex (neither excitement nor attenuation form the right attitude). It is necessary to extract of the meanings from arousals of sexual excitements that make learning the other person possible. The power of sexual drive must be used to bring about union with other person (see Fijałkowski 1991, p. 24-25). Thus, the destructive primacy of gender can be broken. Sexual activity cannot serve as a determinant for moral evaluation of one's humanness. Therefore, the very positive witness of chaste life according to one's state and of purity of celibate people seems crucial ${ }^{32}$.

\section{Conclusions}

Considering the above issues, the following conclusions can be drawn:

a) Christianity presents a positive image of the human person including sexual identity and sexuality. This image is rooted in the Christian theology of creation: a creation with which God shares His love. Therefore, the deepest justification for our care for chastity, including sexual chastity, should be founded not on the struggle against sin but on an appropriate personal development of the human being. Consequently, adequate formation of conscience is necessary, so that the reference point for the (moral) judgement is located beyond the human person. The ultimate source of an appropriate experience of harmony in the physical, moral and spiritual spheres is $\operatorname{God}^{33}$.

32 "Love is the essence of the state of virginity, it is it's heart, it's reviving power. The choice of virginity is based in the love, is initiated and completed in love, is begins in the moment of contemplative and practical discovering of love, it aims in increasing the abillity and desire to do good: therefore it is not mainly resignation from instincts and temptations [...]" (Cencini 2005, s. 21), my translation.

33 "In the depths of his conscience, man detects a law which he does not impose upon himself, but which holds him to obedience. Always summoning him to love good and avoid evil, the voice of conscience when necessary speaks to his heart: do this, shun that. For man has in his heart a law written by God; to obey it is the very dignity of man; according to it he will be judged. Conscience is the most secret core and sanctuary of a man. There he is alone with God, Whose voice echoes in his 
b) The incarnational model is the foundation of Christian anthropology. This model, in imitation of the divine and human state of the Incarnate Son of God, expresses the coexistence of separate orders in one person: the earthly and supernatural, the temporal and eternal, the physical or bodily and spiritual. These aspects of humanity are not opposition, not constricting nor contesting forces, but on the contrary they demand unity. That constitutes the deepest expression of harmonious development of a person and his and her maturity.

c) Biblical and doctrinal truth about the corporeality of the human person should be adequately presented to the members of the Church in an updated manner, and subsequently it should be presented to all those outside the Church. The moral evaluation of particular cases of what the faithful, taking into consideration the Magisterium of the Church, view to be inappropriate behaviour, still presents a great challenge. Therefore, an appropriate catechesis and deeper and renewed theological reflection on the various issues raising most controversy is necessary.

d) A positive image of sexuality serves as a solid alternative for flawed world views that degrade what it means to be human, especially with regard to progressive sexualisation and gender ideology. A recognition of and respect for of what comes from nature is necessary ${ }^{34}$.

e) Walter Schubert's statement is still valid: "Religion and sexuality are the two most powerful vital forces. Whoever uses them as two primitive antagonistic forces, teaches the age-old dualism of the soul. One who perceives these powers as persistently hostile forces, breaks the human heart" (Fijałkowski 1991, p. 14).

depths" (GS 16). The truth and free will meets in revealing the truth beyond human itsefl. See Finn 2000 , p. 19-21, my translation.

34 "Therefore there can be no true promotion of man's dignity unless the essential order of his nature is respected. Of course, in the history of civilization many of the concrete conditions and needs of human life have changed and will continue to change. But all evolution of morals and every type of life must be kept within the limits imposed by the immutable principles based upon every human person's constitutive elements and essential relations - elements and relations which transcend historical contingency" (PH 3). 


\section{KATOLICKA DOKTRYNA I DUCHOWOŚĆ WOBEC WSPÓŁCZESNEGO ROZUMIENIA SEKSUALNOŚCI}

\section{STRESZCZENIE}

W dyskusji o seksualności człowieka oraz postępujących zmianach obyczajowych konieczne jest pozytywne chrześcijańskie rozumienie płciowości i seksualności. Nie można jednak ograniczać się tylko do prezentowania oceny moralnej poszczególnych aktywności seksualnych. Potrzebne jest rozpoznanie głębokich podstaw doktrynalnych. Wśród nich należy wskazać: tożsamość płciową opartą na fakcie stworzenia, jedność porządku fizycznego i duchowego, doczesnego i wiecznego, co jest realizacją modelu chrystologicznego (inkarnacyjnego).

Przyjmowanie tej podstawy prowadzi do konstruktywnej odpowiedzi na wyzwania współczesności. Postulat integralności człowieczeństwa oraz właściwe powiązanie cielesności i duchowości przezwycięża seksualizację człowieka, ograniczanie seksualności do wymiaru fizycznego, wprowadzanie w niewolę ciała, ale jednocześnie dewaluację płciowości i aktywności seksualnej czy postulowania niejako angelizmu jako ideału dojrzałości ludzkiej. Chrystologiczny model zakłada harmonię i jedność wewnętrzną każdej osoby.

Słowa kluczowe: chrześcijańska antropologia; wyzwania etyki seksualnej; katolickie rozumienie seksualności

\section{CATHOLIC DOCTRINE AND SPIRITUALITY AND THE CONTEMPORARY UNDERSTANDING OF SEXUALITY}

\section{SUMMARY}

A positive, Christian understanding is necessary in the discussion about human sexuality and sexual liberation. However, it cannot be limited to presenting the moral evaluation of sexual activities. A deep doctrinal foundation is needed. This should include: (1) gender identity based on the fact of creation, (2) physical and spiritual, earthly and eternal unity all being the realization of the Christological (incarnational) model.

Accepting this attitude leads to the constructive response to the challenges of contemporary world. The claim of integration of all aspects of humanity and accepting the relation between corporeality and spirituality overcomes sexualization and reduction of sexuality to just the physical act, enslavement of the body and devaluation of sexuality and sexual activities and the suggestion that angelism could be an ideal of 
human maturity. The Christological model presumes harmony and integrity of each person.

Keywords: Christian anthropology; challenges of sex ethics; Catholic understanding sexuality

\author{
ABBREVIATION \\ AAS - "Acta Apostolicae Sedis" \\ AL - Francis, Post-Synodal Apostolic Exhortation Amoris Laetitia \\ DCE - Benedict XVI, Encyclical Deus caritas est \\ FC - John Paul II, Apostolic Exhortation Familiaris consortio \\ HV - Paul VI, Encyclical Humanae vitae \\ GS - Second Vatican Council, Pastoral Constitution on the Church in the Modern World "Gau- \\ dium et spes" \\ PH - Congregation for the Doctrine of the Faith, "Persona humana". Declaration on certain \\ questions concerning sexual ethics \\ MF - Congregation for Catholic Education, Male and Female He Created Them: Towards a path \\ of dialogue on the question of gender theory in education \\ WW - Sacred Congregation for Catholic Education: Educational guidance in human love
}

\title{
BIBLIOGRAPHY
}

„Acta Apostolicae Sedis” Commentarium Officiale (1951), 43.

Babik M. (2003), Wspótżycie seksualne w nauczaniu biblijnym, Kraków.

Bartnik C.S. (2000), Dogmatyka katolicka, t. 1, Lublin.

Benedict XVI (2006), Encyclical Letter Deus caritas est, http://www.vatican.va/content/benedict-xvi/ en/encyclicals/documents/hf_ben-xvi_enc_20051225_deus-caritas-est.html [used: 1.12.2019].

Bouyer L. (1982), Wprowadzenie do życia duchowego. Zarys teologii ascetycznej i mistycznej, thum. L. Rutowska, Warszawa.

Cascone M. (2002), Seksualność darem mitości, tłum. O. Seneta-Niemiec, Kraków.

Cencini A. (2005), Dziewictwo i celibat dzisiaj. W kierunku seksualności paschalnej, tłum. A. Spurgjasz, Kraków.

Chantraine G. (2000), Chrystus wczoraj i dziś, tłum. L. Balter, w: Tajemnica Trójcy Świętej, Kolekcja „Communio” 13, red. L. Balter, [Poznań], s. 165-186.

Chrostowski W. (2000), Ludzka cielesność jako obraz Boga, „Collectanea Theologica” $70 \mathrm{nr} 4$, s. $5-19$.

Congregation for Catholic Education, "Male and female He created them". Towards a path of dialogue on the question of gender theory in education, http://www.educatio.va/content/dam/cec/ Documenti/19 0997 INGLESE.pdf [used: 20.12.2020].

Daniélou J. (1984), Historia Kościoła. Od początków do roku 600, thum. M. Tarnowska, Warszawa. Dlaczego homoseksualiści tak często popetniaja samobójstwa?,

https://homoseksualizm.edu.pl/co-mowi-nauka/34-psychologia/183-dlaczego-homoseksualisci-takczsto-popeniaj-samobojstwa [used: 2.07.2019].

Dziewiecki M. (2000), Cielesność, ptciowość, seksualność, Kielce.

Fijałkowski W. (1991), Seks okietznany? Twórcze przeżywanie płci, Wrocław. 
Finn Th. i D. (2000), Miłość, seks i Kościót katolicki, tłum. A. Oćwieja, Kraków.

Flandrin J.-L. (1998), Historia rodziny, tłum. A. Kuryś, Warszawa.

Francis (2016), Post-Synodal Apostolic Exhortation Amoris laetitia, http://w2.vatican.va/content/ francesco/en/apost_exhortations/documents/papa-francesco_esortazione-ap_20160319_amo ris-laetitia.html [used: 1.11.2019].

Francis (2014), Address of Pope Francis to Members of the International Catholic Child Bureau (Bice), http://w2.vatican.va/content/francesco/en/speeches/2014/april/documents/papa-france sco_20140411_ufficio-cattolico-infanzia.html [used: 15.11.2019].

Fromm $\bar{E}$. (1992), Dogmat Chrystusa i inne pisma religioznawcze, tłum. K. Kosior i in., Lublin.

Gesché A. (2005), Chrystus, tłum. A. Kuryś, Poznań.

Grossi V., Ladaria L.F., Lécrivain Ph., Sesboüé B. (2001), Człowiek i jego zbawienie. Antropologia chrześcijańska: stworzenie, grzech pierworodny, usprawiedliwienie i taska, rzeczy ostateczne. Etyka chrześcijańska: od ,autorytetów” do Magisterium, thum. P. Rak, Kraków.

Grün A., Riedl G. (2006), Religia i seksualność, thum. M. Labiś, Kraków.

Jan Paweł II (1982), Apostolic Exhortation Familiaris consortio, Kraków. http://www.vatican.va/ content/john-paul-ii/en/apost exhortations/documents/hf jp-ii_exh 19811122 familiaris-con sortio.html [used: 15.11.2019].

Knotz K. (2001), Akt matżeński. Szansa spotkania z Bogiem i wspótmatżonkiem, Kraków.

Kołakowski L. (1999), Mini-wykłady o maxi-sprawach. Seria druga, Kraków.

Lombard P. (2015), Cztery księgi sentencji, t. 2, tłum. J. Wojtkowski, Olsztyn.

Misiaczek A. (1996), Zagrożenia moralne młodzieży wyzwaniem dla duszpasterstwa, Pelplin.

Paul VI (1994), Encyclical Letter Humanae vitae, http://www.vatican.va/content/paul-vi/en/encycli cals/documents/hf_p-vi_enc_25071968_humanae-vitae.html [used: 15.08.2019].

Sacred Congregation for Catholic Education, Educational guidance in human love. Outlines for sex education, http://www.vatican.va/roman_curia/congregations/ccatheduc/documents/rc_con_cca theduc_doc_19831101_sexual-education_en.html [used: 13.07.2019].

Sacred Congregation for the Doctrine of the Faith, "Persona humana". Declaration on certain questions concerning sexual ethics, https://www.vatican.va/roman_curia/congregations/cfaith/do cuments/rc con cfaith doc 19751229 persona-humana en.html [used: 15.08.2019].

Sawa P. (2009), Misterium Wcielenia. Rzeczywistość, inspiracje, nadzieje, Katowice.

Second Vatican Council, Pastoral Constitution on the Church in the Modern World "Gaudium et spes", http://www.vatican.va/archive/hist_councils/ii_vatican_council/documents/vat-ii_cons_19651207 gaudium-et-spes_en.html [used: 20.12.2019]

Szymik J. (2014), Teologia Wcielenia dzisiaj, „Śląskie Studia Historyczno-Teologiczne” 47/2, s. $292-305$

Szymik J. (2004), W świattach Wcielenia: chrystologia kultury, Katowice-Zabki.

The Epistle of Mathetes to Diognetus, http://www.newadvent.org/fathers/0101.htm [used: 31.12.2019]

Tomasz z Akwinu (1967), Suma teologiczna, t. 10: Uczucia, tłum. J. Bardan, London.

Tomasz z Akwinu (1982), Suma teologiczna, t. 32: Małżeństwo, tłum. F.W. Bednarski, London.

Waldenfels H. (1997), Odkrywać Boga dzisiaj, tłum. B. Białecki, Kraków.

Wiśniewska-Roszkowska K. (1988), Seks i moralność. Rozważania. Dyskusje. Polemiki, WarszawaStruga-Kraków.

Wyznanie wiary soboru chalcedońskiego, $451 \mathrm{r}$., w: Breviarium fidei. Wybór doktrynalnych wypowiedzi Kościoła, red. I. Bokwa, Poznań 2007, s. 70-74.

Zwoliński A. (2014), Cyberseks, Kraków. 
Rev. Przemysław Sawa - is a priest of Diocese of Bielsko-Żywiec. He is a Doctor of Dogmatic Theology and an assistant professor in The Department of Dogmatic Theology and Spirituality at the Faculty of Theology of the University of Silesia in Katowice. His work focuses on the interconnectedness between dogmatic theology and spirituality, ecclesiology and evangelical and charismatic spirituality. He is the founder of the Cyril and Methodius School of Evangelisation. He was appointed a Missionary of Mercy by Pope Francis. 